\title{
Physical and oxidative stability of fish oil-in-water emulsions stabilized with fish protein hydrolysates
}

García Moreno, Pedro Jesús; Guadix, Antonio ; Guadix, Emilia M. ; Jacobsen, Charlotte

Publication date:

2015

Document Version

Peer reviewed version

Link back to DTU Orbit

Citation (APA):

García Moreno, P. J., Guadix, A., Guadix, E. M., \& Jacobsen, C. (2015). Physical and oxidative stability of fish oil-in-water emulsions stabilized with fish protein hydrolysates. Abstract from 106th AOCS Annual Meeting and Industry Showcases, Orlando, Florida, United States.

\section{General rights}

Copyright and moral rights for the publications made accessible in the public portal are retained by the authors and/or other copyright owners and it is a condition of accessing publications that users recognise and abide by the legal requirements associated with these rights.

- Users may download and print one copy of any publication from the public portal for the purpose of private study or research.

- You may not further distribute the material or use it for any profit-making activity or commercial gain

- You may freely distribute the URL identifying the publication in the public portal

If you believe that this document breaches copyright please contact us providing details, and we will remove access to the work immediately and investigate your claim. 


\title{
PHYSICAL AND OXIDATIVE STABILITY OF FISH OIL-IN-WATER EMULSIONS STABILIZED WITH FISH PROTEIN HYDROLYSATES
}

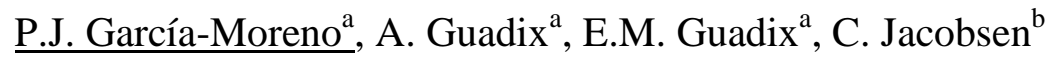 \\ ${ }^{\mathrm{a}}$ University of Granada, Granada, Spain \\ ${ }^{\mathrm{b}}$ Technical University of Denmark, Lyngby, Denmark
}

To successfully develop food enriched with omega-3 PUFA, lipid oxidation of these highly unsaturated fatty acids must be prevented in order to avoid both the loss of nutritional value and the formation of unpleasant off-flavors. In this sense, one of the strategies developed to protect these oxidative unstable lipids when incorporating them into food is the employment of delivery systems such as fish oil-in-water emulsions. In these systems, the emulsifier determines the structure and thickness of the interfacial layer, which is the place of contact between lipids and prooxidative components. ${ }^{1}$ Thus, emulsifiers exhibiting also antioxidant activity are preferred in order to reduce lipid oxidation. In this context, fish protein hydrolysates could be good candidates to be employed as emulsifier due to their recognized emulsifying and antioxidant properties. ${ }^{2}$

In the light of the above, the objective of this work was to investigate the influence of sardine fish protein hydrolysates on the physical and oxidative stability of fish oil-in-water emulsions. For that purpose, four hydrolysates with different degree of hydrolysis $(3,4,5$ and $6 \%)$ and obtained by using subtilisin were evaluated. Firstly, the antioxidant capacity of the hydrolysates was tested by in vitro assays (DPPH, chelating activity and reducing power). Secondly, the physical stability of the emulsions was determined by measuring their viscosity, zeta potential and droplet size. Finally, in order to determine the oxidative stability of the emulsions, analysis of peroxide value, tocopherols content and volatile oxidation products were carried out. The stable emulsions produced are susceptible to be used directly as omega3 delivery systems in order to produce fortified food.

\footnotetext{
${ }^{1}$ Hunt, J.A., \& Dalgleish, D.G. (1994). Adsorption behaviour of whey protein isolate and caseinate in soya oilin-water emulsions. Food Hydrocolloids 8: 175-187.

${ }^{2}$ Klompong, V., Benjakul, S., Kantachote, D., \& Shahidi, F. (2007). Antioxidative activity and functional properties of protein hydrolysate of yellow stripe trevally (Selaroides leptolepis) as influenced by the degree of hydrolysis and enzyme type. Food Chemistry 102: 1317-1327.
} 